World Maritime University

The Maritime Commons: Digital Repository of the World Maritime University

\title{
An engineer on board a marine research vessel: proposal for education and extra-curricular activity toward the creation of value
}

Hironori Funatsu

Seafarer Group

Follow this and additional works at: https://commons.wmu.se/imla2021

Part of the Education Commons

\section{Recommended Citation}

Funatsu, H. (2021). An engineer on board a marine research vessel: proposal for education and extracurricular activity toward the creation of value. In Pazaver, A., Manuel, M. E., Bolmsten, J., Kitada, M., Bartuseviciene, I. (Eds.), Proceedings of the International Maritime Lecturers' Association. Seas of transition: setting a course for the future (pp. 41-45). World Maritime University. http://dx.doi.org/ $10.21677 /$ imla2021.03

This Paper is brought to you courtesy of Maritime Commons. Open Access items may be downloaded for noncommercial, fair use academic purposes. No items may be hosted on another server or web site without express written permission from the World Maritime University. For more information, please contact library@wmu.se. 
http://dx.doi.org/10.21677/imla2021.03

\title{
An engineer on board a marine research vessel: Proposal for education and extra-curricular activity toward the creation of value
}

\author{
Hironori Funatsu \\ Chief Engineer, Member of Seafarer Group Hatokai, Tokyo, hikaku272@kub.biglobe.ne.jp
}

\begin{abstract}
Seafarers do not come in the foreground in society and support their country from locations away from many nations. Under such a special circumstance, the Happiness Of Life At Sea (HOLAS) as seafaring is a life, both on board and ashore, where seafarers acquire and achieve their own value in themselves internally. Here I consider and propose, through my personal experiences, value-creating activities which we must address as part of maritime education and extra-curricular from now on.
\end{abstract}

Keywords : value-creating education, unseen virtue and visible reward

\section{$1 \quad$ Introduction}

Is there no equipment lacking?

Are there sufficient materials available to respond to potential problems?

I examine against a checklist, time and time again, the items contained in suitcases which have already been packed. After the departure of the members, there is no way other than locally procuring necessary materials. The task to reduce such risks as far as possible is one of the duties of a person in charge of equipment. It is a continuation of a dull, mindless job no one wants to do and, at times, I myself want to throw it away. However, on hearing that the photograph exhibition was a success, I am filled with delight to have learned that the solitary effort made up to the point in time has borne fruit. I have found it is a supreme joy which only those who have made a painful effort can feel and I have tasted the pleasant feeling. I recently understood that this is the meaning in terms of the value of preparatory work. When you truly realize that your assigned role is your own mission, you can greatly feel a sense of fulfillment and accomplishment.

\section{1-1 Marine Research Vessel}

Working as an engineer on board the ocean research vessel for 30 years, I have been engaged mainly in general operations of the engine department (maintenance of engines and their related equipment) and the upkeep of a hydraulic type winch system used for sampling by researchers.

Researchers do not want to be deprived of their research time by a problem with an observation instrument, so we devote ourselves to the maintenance of such instruments at other times. Even 
so, trouble occurs without any warning and, in such a case, we are forced to conduct restoration operations in a hurry. Jobs with time restrictions demand extreme care, and fray our nerves.

The main duty of vessels engaged in drilling or ocean research is observation work and, unlike cargo ships and other kinds of vessels, these vessels have a feature that operation departments (i.e., deck and engine departments) exist in the background to provide supporting work. It is not confined to research vessels but, on board such vessels, especially required is an attitude to perform his duties proactively while increasing his motivation for work. For this reason, it is important for crew to find and create value for their duties, they may often accumulate stress from personal relationships.

\section{1-2 The way seafarers use their vacation}

Seafarers pass their days on board by using various methods to refresh themselves but how do they spend their vacations they have waited for?

When it comes to seafarers' vacations, it is common for them to use them to recover both mentally and physically from their work or to devote themselves to family duties. However, in my case, as I am a member of a group of seafarers co-hosting this photograph exhibition, activities to hold a photograph exhibition are the main pillar of my vacation. I hope that activities for this photograph exhibition may contribute to the spread, in the world of the shipping industry and seafarers, of education which places importance on peace and culture.

\section{Photo Exhibition at IMO, IMLA and other world maritime educational fields}

The photo exhibit "Beyond the Horizon" has been held since 1987 by Japanese seafarers. The permanent photo exhibition, displayed since 2008 in the headquarters of IMO, was established in the hope that those people involved in preparing conventions and laws know the actual world of seafarers. For the 70th anniversary of the conclusion of the IMO Convention, the theme of the exhibition is "HOLAS for SOLAS", in collaboration with the IMLA, which was transferred to World Maritime University next year. Although such exhibits are permanently displayed in nineteen maritime academies in the world, we would like to continue them by replacing photographs every year, with the theme of "HOLAS (Happiness of Life at Sea) for SOLAS".

\section{$3 \quad$ For bringing a photograph exhibition to a success}

\section{3-1 Support in the background-importance of general affairs-}

Before the date of an exhibition and lectures, various tasks are required to be done, such as negotiation, communication, dispatch of personnel, study of the contents of lectures, preparation of photographs, preparation for setting up the exhibition venue, and bringing in photographs. If we liken negotiation for lectures or the provision of guidance and explanations through the exposition, to the 'centre stage', general affairs, such as the preparation of photographs and the setting up of such a display, may be low-profile 'back stage work'. Although the latter operations are inconspicuous, they are vital ones without which the display of photographs cannot be held successfully. 
Even among us, the members of 'Hato Kai', such members who can carry out these tasks are limited. With the absence of such members to carry out such low-profile jobs, I, myself, have been forced to do so for many years. Thanks to this situation, I have become an expert.

\section{3-2 Unseen Virtue and Visible Reward}

In Japan, there is a training of 'Hanto'. In the Japanese art of tea ceremony, Hanto is a person who assists the host in going through a tea ceremony. To become a master of the tea ceremony, this training of Hanto is considered most important.

I am not good at negotiation or speaking before many people. For this reason, I found my life meaningful when I made up my mind to devote myself to background battles instead of work in the foreground. This is the principle of cherry, plum, peach and damson blossoms. It suffices if a person shines in their position or in their field. It is most important to find value in their position. At the same time, the joy of a person who has obtained their own mission is immeasurable. It is more fortunate to encounter a leader who can cast light on each person's personality, strong points, and give a suitable mission.

Dr. Daisaku Ikeda, The founder of Soka University Japan, quotes words from Huainanzi (ancient Chinese collection of essays) and intends as followings

\section{Quote "What is done by night, appears by day."}

\section{Unseen Virtue: To do good by stealth}

\section{Visible Rewards: Tangible Outcomes}

Who pursues open rewards without doing good by stealth, is not walking the right track of life. Because they cannot understand the law of cause and effect, they slack off in their efforts and have weakness to avoid troubles. Doing good by stealth means a person who spends all of one's energy to act sincerely whether it is recognized by someone or not. Though we can't know when rewards will come back to us, Unseen Virtue certainly will appear as an Opened Reward.

This is the philosophy of Winter Always Turns to Spring. Leaders and Educators must enlighten human resource who spends all of one's energy to what is done by night.

I do intend that this basic policy is the most important guideline for seafarers and must be infiltrated into the young generation who aspire to work for maritime society.

\section{3-3 Actual record of photograph exhibitions in IMO}

In June 2008, I was involved in a photograph exhibition held at IMO in London. As you are aware, IMO, because of its importance, imposes various restrictions, such as the screening of visitors from outside, instruction in relation to the contents of operations.

Concerning the method of display, we underwent various simulations thoroughly over several months on the basis of a prior survey. We also paid attention to minimize the items to stuff 
suitcases with, such as photograph panels and other equipment for the exhibition. The time allowed to set up the display in the IMO headquarters was restricted to six hours and we managed to complete it at the last minute by using the entire time, while discussing, among all of us, the arrangement of partitions so that visitors might enjoy the exhibition fully. The ceremony to celebrate the 100th session of IMO was held in the lobby on the first floor of its headquarters. It was honoured by the attendance of Mr. Ban Ki-moon, the ex Secretary General of the United Nations.

During the work for the exhibition, when I directed my eyes to the outside through the windows, Westminster Abbey and Big Ben over and along the river Thames, came into view.

While thinking 'Oh, this is London,' I was engrossed in the operation, with my eyes lowered. Suddenly a thought occurred to me: "Heavens! What am I doing now?" What I am doing now has no difference from what I do in the Tokyo office. I was taken by a strange illusion like an instant shift from Tokyo to London and was wondering "Where am I now?"

That is, this was the moment I understood for the first time that this monotonous preparatory work has connected me with the world. I came to believe, strongly, that what I had been continuing for decades, believing in myself, led me to London while creating my own value.

\section{Conclusion}

\section{4-1 Recommendation of value-creating activities}

Crewmembers who work on board vessels are burdened with various duties in respective departments. What is most painful for those seafarers is when they cannot find value in what they do or when they are not given a mission.

In short, the purpose of life is to acquire happiness for each person and for the society as a whole, and a part of such happiness depends on the creation of value, I think. Happiness of life at sea (HOLAS) as a seafarer means, after all, the state of life where one has acquired and realized value on board and during vacations.

The study of value is not only necessary as a concept of the purpose of life but also inevitable in order to break through shipboard daily life which has never been considered happy, thereby to establish life filled with happiness.

\section{4-2 Function of maritime education}

Young students who are going to work on board ships are filled with various worries as well as hopes. When faced with various difficult realities, how do they overcome them on their own? For seafarers who work on board vessels, a special environment where assistance from the shore is difficult to reach, it is important to improve their ability to accomplish a breakthrough and, while continuing their work, acquire a sense of happiness in their own job and life. While this is a personal aspect, on the other hand, in view of the principle of cherry, plum, peach and damson blossoms, an environment where team members respect the roles and qualities of respective individuals is also important. 
Therefore, even in maritime education, I would like to conclude that the importance and necessity of an educational system of creating value through:

- Fieldwork to participate in various cultural activities outside each individual's own field

- Activities to shed light on strong points of, and give a mission to, each individual; and

- Activities to award those who work in the background,

will increase more and more. 